\title{
E O VERBO FEZ-SE CARNE: A EUCARISTIA ENQUANTO ATO INSTITUINTE DO SER
}

\author{
AND THE WORD BECAME FLESH: THE RITE OF EUCHARIST
}

AS INSTITUTED ACT OF BEING

MAURO MEIRELLES ${ }^{(*)}$

\begin{abstract}
RESUMO
A eucaristia é um rito católico que visa reafirmar a fé cristã. O presente texto ocupa-se, portanto, da eucaristia enquanto ato instituinte do ser e busca pensar o referido rito a partir da perspectiva de Mikhail Bakhtin. Desta feita e a partir do enfoque da antropologia, se ancora em certas sínteses na medida em que, a validade daquilo que se pressupõe verdade, do ponto de vista da cognição, não depende do fato desta ser ou não ser conhecida por alguém. Pois, é o homem que une fé e rito, que une verdades da ciência e fenômenos físicos. Desta feita, tem-se então que, quando postulamos a existência de Deus a partir de certos escritos canônicos - e o reafirmamos no rito eucarístico - lhe conferimos existência e tangibilidade. Sobretudo, defendese no decorrer do texto que a eucaristia, seja enquanto ato instituinte, seja enquanto rito, nada mais é do que uma enunciação de si sobre si que só tem significado, manifesto em seu conteúdosentido, se enunciado por aquele que experimenta e executa $o$ ato.

Palavras-Chave: Eucaristia. Rito Eucarístico. Mikhail Bakhtin. Rito e Fé. Antropologia da Religião.

\section{ABSTRACT}

Eucharist is a Catholic rite that aims to reaffirm the Christian faith. This paper analyzes the Eucharist rite as instituted act of being and aims think that rite in the Mikhail Bakhtin's perspective. So, from an anthropology's approach, it is based in some perspectives that recognize validity in of what is assumed true, in a cognition point of view, depends on whether this is or is not known to anyone. That is because the man is the one who unites faith and rite, truths of science and physical phenomena. Therefore, when we postulate the existence of God from certain canonical writings - and reaffirm the Eucharistic rite, we give him existence and tangibility. Most of all, this text argued that the Eucharist is as instituted act or a rite, is nothing more than a statement of itself that only has meaning, manifest in their content-sense, if enunciated by one who experience and performs the act.
\end{abstract}

KEYWORDS: Eucharist. Eucharistic rite. Mikhail Bakhtin. Ritual and faith. Anthropology of Religion

\section{A FÉ COMO DOXA E A TEORIA EXPLICATIVA DO MUNDO, O RITO COMO CIÊNCIA DO} SOBRENATURAL

A fé ou fides, do latim, enquanto cognato traz consigo implícita em si a ideia ou crença inconteste em uma verdade sem que essa ofereça qualquer prova ou garantia de sua veracidade. Sua força e valor semântico reside, portanto, na

${ }^{*}$ Doutor em Antropologia Social. Professor do Programa de Pós-Graduação em Educação do Centro Universitário La Salle - Unilasalle/Canoas. E-mail: mauromeirelles@icloud.com 
confiança que depositamos nela e/ou naquele que a simboliza ou é, ainda, seu portador reconhecido e autorizado. É impossível duvidar e ter fé ao mesmo tempo, pois, esta última, exige daquele que a professa a ausência total da dúvida.

A fé enquanto um conjunto de relações, como diriam os antropólogos, consiste em um sentimento íntimo, manifesto de forma individual ou coletiva, que produz um sentimento de afeição, de confiança e de aceitação de uma hipótese ou explicação do mundo como verdade, sem a exigência desta resistir a refutabilidade para ser considerada tão ou mais verdadeira quanto for a sua capacidade de resistir a refutações (POPPER, 1963).

Neste sentido, enquanto doxa, tem-se que a fé denotaria simplesmente algo que é dado como certo em uma dada sociedade, em dado período de sua história de modo que, o natural e social, aparecem ao indivíduo como autoevidente (Bourdieu, 1977). A doxa denota, assim como a fé, algo que é tido como uma verdade inquestionável, contudo, diferentemente da primeira, seu alcance não é global e se circunscreve a diferentes contextos e grupos sociais.

Neste sentido, tem-se que a doxa está contida na fé de modo que, a fé em Deus, pode ser tida como uma categoria universal de pensamento, contudo, a forma como cada sociedade se relaciona com a Santíssima Trindade ou com cada uma de suas manifestações irá variar em função do modo como, cada uma das diferentes sociedades e religiões, concebe essa relação com o sobrenatural, com as coisas do sagrado. Distinção esta que têm sua base assentada, pelo menos no âmbito das ciências sociais em específico, nos estudos de Émile Durkheim (1996).

Isto posto, tem-se que a fé e seus atos instituintes, tida como uma forma de explicar o mundo que ocupa o mesmo lugar semântico do mito nas sociedades primitivas e da ciência no mundo contemporâneo, não deixa de ser, assim, uma teoria explicativa de como as coisas são e de como elas devem ser. Dito de outra forma, se antes daquilo que Weber $(1968,2004)$ denomina de desencantamento do mundo o processo de combustão de uma árvore ao ser atingida por um relâmpago era tributária à vontade e ao desejo de um "deus" ou "entidade sobrenatural”.

Hoje, este mesmo evento, têm assento na explicação científica dada pela ciência através dos físicos que mostram ser esse um evento observável na natureza que é tributário a um processo físico-químico relacionado à um 
fenômeno elétrico ocorrido na alta atmosfera que produz uma descarga elétrica de alta intensidade que pode partir da terra em direção aos céus (e vice-versa) que fornece o calor inicial para a ocorrência da combustão do material orgânico contido na árvore (a madeira). Contudo, não existem menores e maiores verdades nesse caso de modo que, ambas as explicações e especulações, feitas por cientistas e xamãs, cada uma a seu tempo e considerada a especificidade daqueles a quem se destina a explicação do referido fenômeno, são tidas por aqueles que a recebem como uma verdade inconteste.

Sendo assim, partindo-se dessa assertiva, de que na ciência também se crê e que, esta, possui suas verdades incontestes, têm então que, a crença na ciência e no processo de racionalização do mundo, grosso modo, pode ser interpretada como um ato de fé. Ou seja, nos ocupemos por exemplo de uma das partículas elétricas mais elementares - o elétron -, sem adentrarmos, aqui, em discussões mais profundas e específicas ligadas a física nuclear como, por exemplo, aquelas que envolvem os quarks e/ou o chamado bosón de Higgs ${ }^{1}$ (conhecida popularmente como a partícula de Deus²).

O elétron, dentro da Física, é tido como uma partícula subatômica de carga elétrica negativa que é responsável pela criação dos campos magnéticos e/ou elétricos e que orbita no entorno do núcleo de um átomo de um elemento químico qualquer variando a sua quantidade em função das camadas Spin necessárias para tornar a massa atômica desse átomo, composta de prótons e nêutrons, estável. Contudo, nos laboratórios de pesquisa nucleares e mesmo nesses, apesar de toda a tecnologia neles empregada, são poucos aqueles que "viram" ou "testemunharam" a sua existência na medida em que "sua existência" se baseia em uma série infindável de registros científicos que atestam suas propriedades.

\footnotetext{
${ }^{1}$ É uma partícula elementar bosônica prevista no Modelo Padrão de partículas que, em tese, teria surgido logo após o Big Bang. Teoricamente, esta, possuiria uma escala maciça hipotética predita para validar o modelo padrão atual de partículas que foi, provisoriamente, confirmado em 14 de março de 2013. Sua existência, é a chave que permite aos físicos explicar a origem da massa das outras partículas elementares. Grosso modo, tem-se que o bóson de Higgs já havia sido predito em 1964 pelo físico britânico Peter Higgs. Contudo, passaram-se cerca de quase 50 anos até que, houvessem condições tecnológicas de se buscar a possível existência do referido bóson. Algo que somente aconteceu em 2008 quando entrou em funcionamento o Grande Colisor de Hádrons (LHC). Contudo, ainda se demoraram quatro anos até que, em 4 de julho de 2012, os cientistas do CERN, anunciassem que uma partícula desconhecida e com massa entre 125 e $127 \mathrm{GeV} / \mathrm{c} 2$ havia sido detectada. Algo que somente se confirmou cerca de um ano depois quando, em março de 2013, conseguiu-se mostrar como a partícula se comportava, interagia e decaía de acordo com as várias formas preditas pelo Modelo Padrão.

2 Ou partícula-Deus (“God particle”) em tradução literal do inglês.
} 
Nesse sentido, apesar deste "famigerado elétron" não ter sido visto, assim como Deus, tem-se que toda a nossa ciência e tecnologia modernas estão postulada a partir da sua existência da mesma forma que, quase a totalidade das religiões do mundo, estão postuladas a partir da existência de Deus. Outrossim, tem-se então que, entendida enquanto um modelo explicativo ou teoria, qualquer afirmação pautada na crença em uma verdade inconteste - e aqui nos referimos ao ato de fé como instituinte do mundo - deve, obrigatoriamente, ser submetida à análise filosófica. Esta, a mesma utilizada por Popper, quando este estabelece uma relação entre ciência e pseudociência comparando os escritos e a recepção das teorias de Albert Einstein, Karl Marx, Sigmund Freud e Alfred Adler.

Disto decorre, entre as conclusões apresentadas pelo referido autor que, a exemplo das teorias do social de Marx, Freud e Adler, a fé, também parece explicar tudo e toda e qualquer realidade, sendo a vida cotidiana e as coisas que acontecem no mundo apenas a prova empírica de sua veracidade. Fato este que lhe dá força e vigor enquanto modelo explicativo ou teoria. Enquanto ciência do sobrenatural. Algo que, se pensado em termos de nosso "famigerado elétron" também torna aquele que acredita na ciência em um "devoto" desta ciência e de seus postulados.

\section{BAKHTIN E A FILOSOFIA DO ATO}

Em "Para uma Filosofia do Ato Responsável”, Bakhtin (2012) está ponderando com Kant seu entendimento acerca dos julgamentos morais e o que ele denomina de "a universalidade do dever" o qual protegeria o agente - ou aquele que julga - do vício moral em potência que existe no ser humano, quando este se usa do relativismo como base para construção do julgamento e para realização de uma leitura do mundo e de seus próprios atos. Contudo, dado o transcendentalismo de Kant, tal sistema se mostra extremante abstrato e de pouco serve para pensar e explicar a subjetividade que está por traz das ações humanas, da leitura que o homem faz do mundo.

Neste sentido, ao pensar o ato em si, longe do transcendentalismo de Kant, Bakhtin tenta recuperar a imediaticidade da experiência nua e crua, em seu estado mais puro e no momento em que ela acontece, e através deste movimento de pensar a experiência no tempo presente, na imediaticidade do experienciado e do vivido, captar os aspectos subjetivos que normatizam e dão sentido a vivência da experiência. Tal experiência é compreendida no momento 
em que acontece, no ato, na ação humana nua e crua, na sua particularidade máxima, manifesta numa vivência específica da experiência humana.

Bakhtin busca pensar o ato - o acontecer da vida - no tempo presente, sem o peso da reflexão que o tempo impõe quando o presente vira passado, sem a ilusão biográfica que organiza e ordena o tempo da vida e do mundo, sem o filtro dos preceitos morais que ressignificam a forma como vemos o mundo quando para trás olhamos e repensamos nossas ações e vivências. Em seu empreendimento intelectual que se substancia em "Para uma Filosofia do Ato", Bakhtin busca, longe da atual distinção que norteia a ciência moderna e a linguística em específico, qual seja, da separação entre a ordem dos signos e a ordem das coisas, pensar o ato e a experiência em si, no momento de sua realização.

Seu objetivo primordial reside, portanto, em compreender o que separa os atos físicos e mentais, entendidos pelo filósofo e linguista russo como um "evento único do Ser" que têm consequências posteriores a sua ocorrência. Neste sentido, como exposto por Michael Holquist no prefácio da referida obra, Bakhtin quer compreender a diferença entre o que é "agora" e o "depois-deagora" e o modo como, o indivíduo, na singularidade de sua existência, estabelece uma relação entre esses dois momentos distintos da experiência e do ato em si. Ou seja, como podem determinados conceitos - que por definição devem ser transcendentais se pensados sob a ótica kantiana e, portanto, livres e independentes da experiência particular - relacionarem-se com minhas experiências subjetivas em toda sua unicidade e servirem a esta, como uma forma de ordenamento de minha experiência sensível no mundo?

Isto posto, e mesmo reconhecendo que as descrições dos atos são uma construção humana subjetiva que difere dos atos tais como eles são realizados, Bakhtin, procura, em suas descrições, livrá-los de qualquer juízo moral e tenta descrever o próprio ato, o ato em si. Neste sentido e na busca de tentar responder à questão supracitada, Bakhtin, ao discutir a relação entre o ato vivido e a representação que fazemos do mesmo (que nunca é a mesma em função do caminho percorrido e da distância que estamos dele e do depois-deagora) se opõe ao princípio transcendental de Kant do "como se", e fundamenta seu argumento no princípio do "não-álibi” ou “evasão de responsabilidade” na existência.

No âmbito filosófico-formal, e não desconhecendo a existência de outras dimensões que devem ser consideradas, tem-se que a principal diferença no argumento construído pelos dois autores reside, fundamentalmente, nos 
princípios que dão base - ou sustentam - aquilo que eles postulam como a base da ação ética. Dessa maneira, tem-se então que, a ação moral, para Bakhtin estaria pautada na responsabilidade e no modo como - nós - relacionamos o "aqui e agora" com o "depois-de-agora". O ato com aquilo que ele representa. Como quando, o pão e o vinho, se tornam o corpo e o sangue de Cristo.

Isto posto, tem-se então que o resultado último da separação entre o conteúdo do ato e o momento de sua realização/experimentação pelo sujeito da ação reside num processo de decantação da objetividade e da subjetividade contida no mesmo, de separar aquilo que está vinculado ao mundo da cultura daquilo que se vincula ao mundo da vida. Decorre dessa proposição que, o ato integral, contém em si, em sua experimentação real, uma dupla natureza que se dirige tanto para o conteúdo (a fé) quanto para o ato em si (o rito eucarístico).

E, desse modo, a reafirmação da fé, através do rito eucarístico, representa o evento em processo e responde tanto pelo seu conteúdo-sentido quanto por aquilo que é, ou pode, em potência, vir a ser. E, essa corresponsividade do ato e seu conteúdo é, então, segundo Bakthin (2012, p. 42-43), o próprio momento constituinte do ato na medida em que

somente na sua totalidade tal ato é verdadeiramente real, participa do existirevento; só assim é vivo, pleno e irredutivelmente, existe, vem a ser, se realiza. É um componente real, vivo, do existir evento: é incorporado na unidade singular do existir que se vai realizando, mas essa incorporação não penetra em seu aspecto de conteúdo-sentido, que reivindica a completa e definitiva autodeterminação na unidade de um determinado domínio de sentido - da ciência, da arte, da história: embora, como mostramos, esses domínios objetivos, fora do ato que os envolve, não são, em si reais.

É, o nosso elétron que só tem sua existência reivindicada no interior de um dínamo ou de um fio incandescente no interior de uma lâmpada ou chuveiro. Ou ainda, na ponta de nossos dedos quando somos eletrocutados, por descuido, ao ligarmos algum dispositivo elétrico. É, portanto, o ato, o fazer-Ser no mundo uma experiência sensível de modo que,

o ato da atividade de cada um, da experiência que cada um vive, olha, como um Jano bifronte, em duas direções opostas: para a unidade objetiva de um domínio da cultura e para a singularidade irrepetível da vida que se vive, mas não há um plano unitário e único em que as duas faces se determinem reciprocamente em relação a uma unidade única. Somente o vento singular do existir no seu efetuarse pode constituir esta unidade única; tudo o que é teórico ou estético deve ser determinado como momento do evento singular do existir, embora não mais, é claro, em termos teóricos e estéticos. (BAKTHIN, 2012, p. 43) 
E, é neste sentido, dando-se conta dessa dualidade latente que está contida no ato em si, assim como da natureza do signo e sua arbitrariedade, como diria Saussure (1996), que não muito dista dessa relação dual quando separa significante e significado, que podemos compreender o ato de fé e o rito eucarístico em sua totalidade. Ou seja, sem separar o mundo da cultura, que dá significado ao símbolo, do mundo da vida, que dá significado ao ato instituinte do Ser.

Deste modo, o ato, enquanto momento instituinte da existência humana e do tempo presente e do agora, se constitui no epicentro de uma teia de sentidos e significados que estão nele contidos e que lhe dá sentido e significação (GEERTZ, 1989). Entendida como forma de expressão do simbólico e da fé, o rito eucarístico pode ser entendido, então, como um discurso que quer dizer alguma coisa, que como ato instituinte confere, por positivação, tangibilidade a existência de Deus. E o ato em si, pensado enquanto discurso seria, portanto, sua elocução única e virginal que, no momento em que é manifesto já deixa de existir, como um gênero primário do discurso que só pode ser vivido com todo seu vigor por aquele que o enuncia (BAKTHIN, 1992).

Quem sobre sua ação reflete e com o ato em si se ocupa, já, no tempo do depois-de-agora, não mais fala dele, e sim, sobre ele, constituindo-se, portanto, num gênero secundário do discurso. E, assim como a mosca que ao enredar-se na teia não é mais mosca e sim alimento, o rito eucarístico fora do momento em que acontece - do tempo de agora e do processo em si do Ser -, do ato instituinte, não é mais fé, e sim, doxa. É a verdade inconteste que confere a Deus, tangibilidade a partir do ato, do rito eucarístico, do "fazer-Ser" e do "fazer-se em si".

\section{FÉ, Rito E MistéRIO}

Neste item me ocuparei de três aspectos que inspirado em Cardita (2007) e no argumento que este desenvolve em sua tese de doutoramento fui instigado a pensar. A reflexão que aqui proponho reverbera por assim dizer, em outros lugares. Primeiro, nas categorias instituintes do social e nas verdades construídas pela doxa, na enunciação do ser no mundo a partir do discurso, na liminaridade do rito e do momento em que se é e não é, ao mesmo tempo, e no conteúdo-sentido que a eucaristia contém em si quando imersa no mundo da vida e da cultura. Depois, na fé, nos escritos canônicos e naquilo que está contido na palavra, na Bíblia e no Catecismo da Igreja Católica, assim como, nos escritos de um de seus maiores teóricos, São Tomás de Aquino. 


\subsection{A FÉ COMO DOXA E ATO INSTITUINTE}

Assim sendo, como bem quer Bakthin (2012, p. 54) somos nós que produzimos as categorias de síntese na medida em que a validade da verdade é uma característica autônoma desta sendo, portanto, eterna e absoluta de modo que, a validade daquilo que se pressupõe verdade, do ponto de vista da cognição, não depende do fato desta ser ou não ser conhecida por alguém. Somos nós que unimos fé e rito. Verdades da ciência e fenômenos físicos.

Somos nós que ao postularmos a existência de Deus a partir de certos escritos canônicos lhe conferimos existência e tangibilidade, da mesma forma que, certa gama de artigos científicos que elencam certas medições elétricas, conferem existência ao elétron permitindo-nos postular toda uma sociedade baseada no uso da eletricidade. Somos nós que fazemos da eucaristia um ato instituinte e que no rito eucarístico consagramos o pão e o vinho tornando-os o corpo e o sangue de Cristo.

E, de forma semelhante, ao consagrarmos a ciência como capaz de "explicar o mundo físico", nós, consubstanciamos a existência dessa partícula subatômica em um feixe elétrico que nos permite escrever esse texto em qualquer computador conectado a uma rede elétrica e, mais, com uma luz incandescente sobre nossa cabeça que devido ao atrito daquele que supomos a existência com certo filamento de metal e envolto por algum gás, produz, luminosidade.

Assim, a fé, enquanto doxa realiza, no interior da religião, seja ela qual for, a comunhão do homem com o sagrado. E que, no interior da ciência, faz comungar, também, o homem em sua existência profana e fenomênica. Mas não é o rito e sua dramatização que faz do dever-ser aquilo que se quer-ser e sim, nossa cognição que diante da verdade (pravda) se faz em verdade instituinte (instina).

$\mathrm{O}$ ato instituinte, visto sobre está ótica, é doxa instituinte do ser. É ato humano e responsável que nossa cognição dota de conteúdo e sentido. E pensar o rito eucarístico fora de sua verdade instituinte (instina), é o mesmo que puxarse pelos cabelos como o fez o Barão de Münchhausen quando com seu cavalo afundava-se na lama e sem ter como sair, puxa a si próprio pelos cabelos para fora desta (LOWY, 1996). O rito eucarístico só pode, então, ser compreendido a partir de sua verdade instituinte (instina) e daquilo que se quer verdadeiro (pravda). 
Só se pode ser aquilo que se quer-ser se conhecemos a verdade daquilo que queremos-ser (instina), e só somos aquilo que somos por que enquanto doxa, esse querer-ser, nos faz-ser (pravda). O ato instituinte, então, fruto de nossa cognição, nos faz-Ser o que somos, e o ato eucarístico - ao mesmo tempo que se institui em sua arbitrariedade - se faz verdadeiro em sua realização, em sua doxa.

Para aquele que têm fé, a validade da verdade (pravda) é suficiente em si, absoluta e instituinte enquanto doxa (instina). É essa sua essência. O rito eucarístico é assim, um momento apenas da historicidade abstratamente conhecida, o momento em que a verdade única (da pravda) acontece na verdade do ato (instina). Deste modo, a eucaristia, enquanto rito e verdade instituída, serve para reviver a fé e as relações com o sagrado daquele que a confirmou ${ }^{3}$.

\subsection{O RITO COMO CIÊNCIA E ATO INSTITUINTE}

O rito surge como forma de instituir o Ser no tempo presente que na fé, faz-se ser aquilo que se quer-ser. É um ato de cognição historicamente datado, no tempo do agora, em seu momento instituinte daquilo que se é e quer-ser. É o fazer-se ser que só tem sentido e significação em si mesmo e para aquele que sofre sua ação instituinte no tempo presente, em sua ação individual (postupok).

Sua veridicidade (pravda), como quer Popper, não é possível de ser experimentada por aquele que a ele se refere ou fala dele, mas sim, somente por aquele que executa o ato, que experiência-o, que o vivencia. Por aquele que institui - o ato em si - enquanto ação responsável e significativa, dotada de sentido para aquele se institui enquanto sujeito e reafirma sua fé, faz deste, também, um ato instituinte em si, de si e do mundo.

E, é no reconhecer do outro, da existência do sagrado - em oposição aquilo que é profano - que eu, ao reconhecer a plenitude do Ser, manifesta na eucaristia, de quando o pão faz-se carne e o vinho faz-se sangue, que reconheço pela aceitação do outro a minha existência. Tal reconhecimento de minha condição enquanto sujeito, enquanto animal humano e racional, faz com que busque na fé, um modo de transcender, de livrar-me do profano. É, portanto, através do ato eucarístico, do rito e da reafirmação de minha fé, daquilo que

3 Na Crisma, ou também, chamado no catolicismo, de Sacramento da Maturidade, uma vez que, o primeiro deles, o batismo já o3recebemos. Contudo, em si, no ato do batismo, pensado na ótica de Bakthin, ainda não respondíamos por nossos atos, e não o enunciamos, sendo, portanto, a eucaristia, a confirmação deste ato primevo. 
acredito e que explica o ser que, faço-me Ser, Ser no mundo. A fé, enquanto momento do dever-ser deriva, pois, desse reconhecimento.

No rito eucarístico, mais do que a presença divina, faz-se presente um conjunto de ações e símbolos que são esteticamente e teoricamente válidos. Esteticamente válidos na medida em que proporcionam ao neófito a presença do divino através de todo um conjunto de sensações psico-sensoriais que são evocadas durante o rito por meio de diferentes dramatizações e alegorias que buscam colocar em evidência o próprio momento catártico e instituinte do ato. Sua validade enquanto teoria, como modo de explicar o mundo, por sua vez, faz-se a partir da fé (pravda) e enquanto doxa (instina) instituinte do ato em si e do rito.

$\mathrm{O}$ rito faz aquilo que se quer-ser, Ser. O momento do dever-ser4 daquilo que se quer-ser5 está completamente ausente do conteúdo dessa determinação e não pode derivar dela (BAKTHIN, 2012). No rito, a fé, enquanto proposição teórica ${ }^{6}$ e a doxa enquanto determinação7, não pode incluir em si o dever-ser e aquilo que se quer-ser. O "Ser" é, assim, constituído na experiência, no momento liminar, em que se é e não é ao mesmo tempo (TuRNER, 1974). A eucaristia, assim, seja enquanto transubstanciação e/ou consubstanciação, ganha valor e existência somente no ato e na dramatização do rito, dentro de sua unidade estética, da unicidade particular da experiência daquele que acede à carne e ao corpo de Cristo.

O ato eucarístico enquanto rito, então, não tem conteúdo determinado. É pão e é vinho que se institui e se consagra. E o rito eucarístico, enquanto categoria da existência é o ato realmente realizado, performatizado, que fenomenologicamente podemos desvelar. Mas desvelar não significa de modo algum aceder a seu significado último, pois este só detém aquele que o enuncia que o vive e o experiencia. De resto, tudo são enunciações sobre, mas não, o ato em si. São mitemas e pequenas histórias que dê algum modo tentam mostrar aquilo que não pode ser visto. É aí que está o mistério ${ }^{8}$. A fonte da fé. Aquilo que institui o homem enquanto homem e diz para ele aquilo que ele pode ser, seu dever-ser responsável.

\footnotetext{
4 Da pravda que se quer instituinte.

5 É que é a instina instituída.

6 E, portanto, pravda.

7 E, portanto, instina.

8 Neste sentido, como escreve Bakthin (2012, p. 85) "Um objeto absolutamente indiferente, totalmente óbvio, não poderia se tornar alguma coisa realmente reconhecida, efetivamente experimentada” pois para que isso ocorra é necessário que eu esteja em relação com ele”.
} 
Assim, a partir de Cardita (2007, p. 183), se conhecemos o sentido e o significado da liturgia tem-se que o homem, no ato eucarístico, poderia, em tese, "entregar-se as atitudes que Ele supõe e reclama”. Neste sentido, do ponto de vista objetivo, a liturgia que envolve o ato eucarístico, recebe de Cristo o seu sentido e, através do ato em si, institui o ser em sua verdade última (instina). Disto decorre que pode o homem, em Cristo, fazer-se pleno, em sua profética realização constante na compreensão do ato eucarístico como instituinte do ser de modo que, o evento em si, enquanto evento em processo, antecipa aquilo que se é desde o batismo e que pode - e, o é - confirmado na consagração eucarística. Sob esta perspectiva, como bem escreve Cardita (2007, p 185),

A multiplicidade ritual deixa de ser um problema para a especificidade cristológica da liturgia cristã, passando antes a confirmar a necessidade do evento cristológico para o sentido do rito cristão e a fazer descobrir a capacidade do rito religioso, enquanto forma antropológica, para permitir acesso a transcendência de Deus na nossa imanência.

Isto, algo não muito diverso da existência tangível do elétron que, através do ato de acender a luz, deixa de lado sua existência transcendente suposta e ganha imanência e tangibilidade no interior de um filamento incandescente de uma lâmpada qualquer. Assim, tem-se que a liturgia e o conhecimento dos ritos cristãos não se apresentam, portanto, à teologia, somente como conhecimento e/ou tradição como bem escreve Cardita (2007, p. 191) mas, também, como um modo de a igreja viver a fé e que, encontra, no Deus-Filho, a sua santificação. Algo que, de modo semelhante à natureza efêmera de nosso elétron que supomos estar lá, mas que se apresenta à nós como uma forma de secularização do mundo, permite a ciência - e ao próprio homem - viver na ascese redentora da racionalidade moderna.

Isto posto, tem-se que, ao observar-se de fora, o rito eucarístico e, também, a imanência de nosso elétron, desconsiderada a dimensão ritual da fé e daquilo que se crê enquanto doxa, esvazia-se de sentido e razão de ser, deixando assim, pelo não reconhecimento do ato instituinte deste - do homo religiosus que celebra o ato eucarístico e/ou do homo cientificicus que a partir da eletricidade postula a imanência do elétron - de existir de modo que, a elaboração cristocêntrica presente no rito eucarístico é, ao mesmo tempo, "revelação" e fé".

Outrossim, no contexto da modernidade, o ato responsável como quer Bakthin (2012) assume contornos diversos que nos levam a considerá-lo a partir da dimensão instituinte do ato "em si” e "per si” de modo que, este, só pode ser 
compreendido em sua totalidade no momento do evento em si, e, a partir da singularidade que lhe confere o evento em processo a partir dos referentes que lhe dotam de sentido, ou seja, do rito, da fé e do mistério que o envolve. Desta feita, tem-se então que o ato eucarístico, enquanto epifenômeno do real, representa a imediatez do agir do homem que se confronta com a santificação operada por Deus no momento da revelação.

Deste giro antropológico, que se gera na modernidade mundo a partir da reestruturação e retomada da dimensão cúltica do ato em si, emerge, a compreensão que tanto a crença em Deus quanto aquela relacionada à preponderância das técnicas e da ciência são, ao mesmo tempo, epifenômenos que convergem numa mesma direção e na manutenção da necessidade humana de crer no transcendente, seja em relação à ciência, seja em relação à religião.

Todavia, se num primeiro momento nos parece paradoxal se referir a ciência como algo que têm um caráter transcendental - como, por exemplo, a suposta existência do elétron - não o é, quando, constatamos que o percentual de médicos que creem em energias/aura é quase igual ao daqueles que, entre a população em geral, creem em Deus, de modo que, do ponto de vista estatístico - a crença em energias/aura enquanto um fenômeno físico - tanto Deus quanto nossa insistente partícula subatômica que insistentemente por este texto transita ocupam o mesmo lugar semântico. Algo que, resumidamente poderia ser sintetizado no seguinte esquema: 


\section{Quadro 1: Esquema Teórico Conceitual - Religião e Ciência}

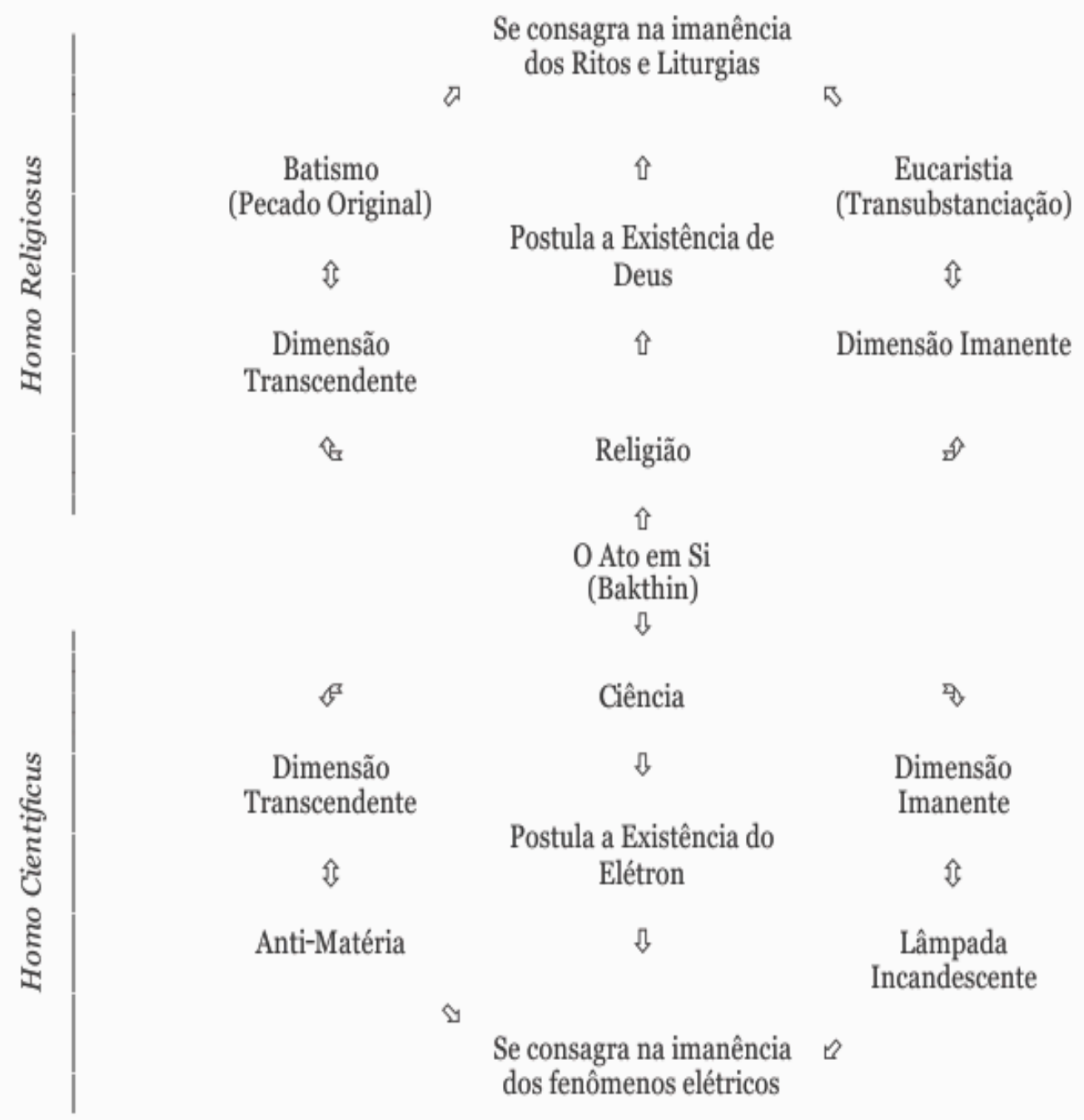

Fonte: Elaboração do próprio autor, inspirado em Cardita (2007, p. 266).

Sobremaneira, dado o exposto, há de se considerar com Rahner (2007, p. 271) que tanto a religião quanto a ciência estão imersas numa transcendentalidade instituinte de enunciados que "correm o risco de serem entendidos como mitologia pelo homem moderno" na medida em que - e sem postularmos os pressupostos ou advogarmos a favor ou contar o etnocentrismo e o relativismo cultural - a crença do outro e aquilo que tanto o homo religiosus quanto o homo cientificus postulam, quando em relação, será visto por seu duplo como enunciados transcendentais que remetem a estruturas de pensamento que se fundam num mito fundante, qual seja, da postulada existência de Deus e/ou do elétron. 


\subsection{O MISTÉRIO COMO INSTITUINTE DAQUILO QUE O HOMEM PENSA DE SI}

A descoberta do mistério como coloca Casel (2007, p. 337) surge na modernidade como "uma forma religiosa apta a receber a novidade cristã" ao mesmo tempo em que permite ao homem moderno a "a reabilitação prática e teórica, ritual e contemplativa" de sua "sensibilidade para o pensamento simbólico". Do ponto de vista de Casel (2007, p. 348), portanto, podemos perceber o ato eucarístico como "uma exterioridade objetiva" que nos permite compreender o próprio ato em si como um epifenômeno de natureza cultural e antropologicamente e teologicamente referenciado.

Desta maneira tem-se que o ato eucarístico pode ser entendido, também, a partir da presença de Deus e da ação salvadora de Cristo presente no culto eucarístico e exige a participação - enquanto ato instituinte - daquele que recebe o sangue e o corpo de Cristo que se transfigura em ato contemplativo, interno e espiritual. Nisto reside, a responsividade do ato em si, da fé que, através do rito eucarístico institui enquanto ato instituinte e verdade última (instina) e santificação que a eucaristia confere ao homem que confirma, através desta, o desejo em potência, manifesto no batismo, de santificar-se no sangue e corpo de Cristo.

Assim, o que homem pensa de si, se institui na fé, seja enquanto pravda, seja enquanto instina. E aquilo que se quer-ser é dado já no primeiro de nossos sacramentos, o batismo. Neste sentido, há de se considerar que, como quer São Tomás de Aquino (ST III, 73: 3), o batismo é o princípio da vida espiritual. É nele que se iniciam os sacramentos, é a partir dele que o homem é orientado a eucaristia. Mas, não é a criança que por desejo faz o batismo e, sim, os adultos, que revivem nela aquilo que foram e o querem que seja em potência. E, assim, como a semente que contêm em potência a árvore (ou o projeto dela), o batismo contém em si, também em potência, sua confirmação através da eucaristia. E, assim, o rito eucarístico retoma e reproduz o acontecimento original de Cristo que junto com os apóstolos dividiu o pão e o vinho na Santa Ceia (MATEUS: 26: 26-28; 1CORINTIOS, 11: 26; JOÃO 6: 53-58; LUCAS, 22: 19-20; entre outros).

Outrossim, o caminho da fé e do encontro da verdade instituinte do Ser manifesta no sacramento eucarístico está, portanto, na nossa cognição, na forma como compreendemos o mundo dos homens e o mundo de Deus. É um mundo que não conhecemos (ou que sim, mas não lembramos). É um mundo em potência, é um mundo que se opõe aquilo que somos, no tempo de chronos, e que se constitui naquilo que podemos vir-a-ser, no tempo de kairós. 
A fé que explica o mundo é a verdade inconteste que resiste a refutação popperiana por ser verdade instituinte (instina). É teoria que se faz doxa (pravda) e que, à incredulidade do ascético, resiste. É aquilo que dá sentido ao ato executado em seu conteúdo-sentido. É, pois, o caminho para instituição do ser no rito eucarístico para o qual a santificação obtida nos demais sacramentos é, apenas, a preparação para sua consagração enquanto Ser único. A eucaristia é, pois, eufemisticamente falando, a confirmação da fé, daquilo que não conhecemos, do mistério do mundo, da vida e de Jesus Cristo.

E para sê-lo, para realizar-se no querer-ser, na instina, o homem deve ter em si o desejo de querer-ser em potência, na pravda. É, portanto, no rito eucarístico que esse querer-ser se faz Ser. É no rito eucarístico que o pão e o vinho se transubstanciam, mesmo que simbolicamente, no corpo e sangue de Cristo, que deixa de ser alimento para o corpo e passa a ser alimento para a alma (JO 6: 54). A eucaristia representa assim, no pão e no vinho, a perfeita união do homem com Cristo, ou como quer São Tomás de Aquino, a comunhão do homem com Ele.

Pois, como esclarece o referido autor (AQUINO, ST III, 73: 1), citando Santo Agostinho, tem-se que o Senhor quer que [a eucaristia] seja entendida como a comunhão de seu corpo e de seus membros que é a Igreja, nos santos e fiéis predestinados, chamados, justificados e glorificados. A eucaristia é, portanto, um dever-ser na medida em que, ninguém deve discutir, de modo algum, que cada fiel se torna participante do corpo e sangue do Senhor, quando no batismo se faz membro do corpo de Cristo. E, também, é, um querer-ser na medida em que não deve julgá-lo [a aquele que foi batizado e ainda não confirmou sua fé como] alheio à comunhão do pão e do cálice, mesmo que, constituído na unidade do corpo de Cristo, parta deste mundo antes de comer daquele pão e de beber do cálice. Isto posto, é o momento agora de nos ocuparmos da liturgia em si e de seu significado.

\section{A LITURGIA SACRAMENTAL: POR UMA ECOLOGIA DA FÉ E DAS DOXAS INSTITUINTES}

A liturgia, como bem querem aqueles que dela se ocupam, nada mais é do que uma celebração religiosa pré-definida que têm assento em uma dada tradição religiosa. Em geral, refere-se a um conjunto de ritos formais9 que reelaboram aquilo que se é e que se pode vir a ser. São representações

\footnotetext{
9 Neste caso, estes, constantes na segunda parte" do Catecismo da Igreja Católica, sob o título "A celebração do Mistério Cristão". Disponível em:

http://www.vatican.va/archive/cathechism_po/index_new/index-seconda-parte_po.html
} 
simbólicas que, dramatizadas na experiência e vivencia do fiel, evocam um certo devir, este, simbólico, que aprendemos a perceber através do desenvolvimento de nossa sensibilidade a partir do ritual que o evoca (CASEL, 2007).

Neste sentido, é essencial que haja certa correlação entre o ato em si no momento do "aqui" e "agora" e o ato per si no momento do depois-de-agora. Pois, é somente essa consciência de si e do ato em si que garante o retorno ao momento em si no tempo do depois-de-agora. É, a partir de fora e olhando para o ato em si que, no momento do depois-de-agora, compreendemos o ato per si. É, essa dualidade estética, do Jano bifronte, que conforma sua individualidade virginal enquanto discurso de si e sobre si.

E, é olhando de fora, para o ato per si que a matéria cega ganha vida, que o pão e o vinho se transubstancia e não mais volta a ser o que era, ou ainda que, de outra perspectiva, se consubstancia, sendo e não sendo ao mesmo tempo. É do "verbo que se faz carne" e da "carne que se faz verbo" que nos ocuparemos agora.

\subsection{A EUCARISTIA COMO TRANSUBSTANCIAÇÃO: E O VERBO FEZ-SE CARNE}

É apenas no ato, na confirmação da minha fé, que o verbo se faz carne ${ }^{10}$. Que entre os meus, na liturgia do símbolo, que evoca o transcendente que me faço pessoa e persona. É na verdade última da doxa e da fé que me faço ser o que sou e que comungo com Ele.

A aliança que neste momento se estabelece assenta-se na redenção da vida eterna e na confirmação do meu devir. É uma enunciação de primeiro grau daquilo que sou e que quero ser. E, sou apenas eu que no ato eucarístico reafirmo minha fé, de modo responsivo, e me faço ser no corpo e sangue de Cristo, consagrado.

$\mathrm{O}$ ato realmente executado de algum modo conhece e possui essa comunhão entre eu e Ele. Na sua fatualidade cotidiana da liturgia católico-cristã a eucaristia reafirma, no tempo dos homens, o tempo de Deus. Neste sentido, como coloca Bakthin (2012), de dentro do ato realizado tudo é uno e concreto e a verdade responsiva (pravda) se torna verdade instituinte (instina).

\footnotetext{
10 Diferentemente dos reformados, e em especial, aqui me refiro a Lutero que não aceita a transubstacialização pois como Consta no Catecismo Maior (n. 161) "O luteranismo sustenta que Cristo, a partir da consagração, junta-se objetivamente à substância dos elementos eucarísticos consagrados. A essa doutrina, chamam de "consubstanciação"; isto é, Cristo está real e pessoalmente com a substância sacramental. Portanto, o fiel luterano também, e concretamente, ingere o Cristo encarnado com o pão e o vinho".
} 
$\mathrm{O}$ ato realizado, desse ponto de vista, do verbo que se faz carne, tem, portanto, um único plano e princípio que abrange sobre si todos os momentos de sua existência tanto no "aqui" e "agora" quanto no depois-de-agora. A transubstanciação do pão e do vinho que, consagrados, tornam-se o sangue e o corpo de Cristo, é o ato realizado e, portanto, o resultado ou soma final, de uma conclusão definitiva, consumado (BAKTHIN, 2012).

$\mathrm{O}$ ato realizado, de consumir a corpo e o sangue de Cristo, não mais alimento do corpo e sim da alma, consuma a comunhão e constitui-se, enquanto ato instituinte, na passagem de uma possibilidade em potência, esta, contida no sacramento do batismo, para aquilo que se quer de fato na vida adulta, que reafirmamos na crisma e o consagramos na eucaristia.

\subsection{A EUCARISTIA COMO CONSUBSTANCIAÇÃO: E A CARNE FEZ-SE VERBO}

Já a consubstanciação como aquilo que é e não é ao mesmo tempo, não exige, de certa forma, e até certo ponto, a confirmação da fé, mas a pressupõe ${ }^{11}$. Quando a carne faz-se verbo ela consubstancia-se através da palavra, do verbo. E o pão e o vinho passam a deter, ao mesmo tempo e no processo uma dupla natureza, de sagrado por que faz-se verbo, de alimento porque faz-se carne.

Fora do momento litúrgico e das estreitas cadeias de conteúdo-sentido, a encenação da Santa Ceia no protestantismo, assim como no catolicismo, simboliza um momento de aliança. Mas uma aliança e comunhão que se dá somente no processo em si e no interior de suas práticas. Por isso a necessidade de, neste, e em suas vertentes reavivadas, tais como o pentecostalismo e o neopentecostalismo, a todo dia e toda hora se reafirmar a fé.

Do lado de fora e longe do processo em si - da celebração da Santa Ceia o dever-ser deixa de Ser. O corpo vira pão e o sangue vira vinho. Seu caráter imanente de desfaz e sua presença se esvazia de modo que, seu conteúdosentido, fora do ato em si, não faz mais sentido. Ou, como diz Bakthin (2012, p. 83-84) a ele, ao fiel,

[...] simultaneamente lhe é dado o valor, concreto e realmente afirmado, destas pessoas, destes objetos, dos quais intui a vida íntima e seus desejos; e, fica-lhe claro também o sentido real e o sentido que merece consideração por conta das relações recíprocas entre ele, estas pessoas e estes objetos.

${ }^{11} \mathrm{E}$, aqui, me refiro, especificamente ao Luteranismo. 
Disto decorre que é a partir da vida interior e dos desejos do indivíduo que com os outros e que com estes objetos comunga que o sentido real do dever-ser deve ser compreendido, ou seja, do ato realizado. Dever esse, real e concreto e não lei abstrata manifesta no caráter imanente de Deus em suas diversas formas e expressões. É nessa totalidade, do ato executado (pravda) e da verdade instuinte (instina) que a carne faz-se verbo e a presença de Deus passa a ser algo que pode ser alcançado de modo que, segundo o referido autor (2012, p. 84) este mundo-como-evento não é somente o mundo do existir, da dádiva. É, também, um mundo instituído que é dado pelo ato.

\subsection{DOS RITOS INSTITUINTES E DO ATO DE FAZER-SER: DOS SACRAMENTOS E DA EUCARISTIA}

Todo sacramento parece deter em si certa dose de mistério que como vimos faz parte daquilo que nos faz ser o que somos e que, de certa forma, dá força e vigor a religião. Por contiguidade e por estar no campo do sagrado e não das coisas mundanas os sacramentos são assim atos extraordinários que dramatizam minha vivência no mundo e minha relação com o sagrado. Os ritos, por assim dizer, são parte da ecologia desse sistema e tem por objetivo a comunhão do homem com o Deus-Filho.

A palavra sacramento deriva de sacralizar, e, por conseguinte, de tornar sagrado. No interior da maioria das confissões cristãs não reformadas os sacramentos são tidos como um sinal ou gesto divino instituído por Jesus Cristo que têm nos escritos canônicos sua referência reconhecida. No Compêndio do Catecismo da Igreja Católica ${ }^{12}$, os sacramentos são sinais sensíveis e eficazes da graça, instituídos por Cristo e confiados à Igreja, mediante os quais nos é concedida a vida divina (n. 224) de modo que Cristo confiou os sacramentos à sua Igreja (n. 226), pois os sacramentos não apenas supõem a fé como também, através das palavras e elementos rituais, a alimentam, fortificam $e$ exprimem (n. 228). E deste modo, ao celebrá-los, a Igreja confessa a fé apostólica. Daí o adágio antigo: «lex orandi, lex credendi», isto é, a Igreja crê no que reza (n. 228).

Disto decorre como coloca São Tomás de Aquino em sua Suma Teológica ${ }^{13}$ (ST III, 60: 1) que os sacramentos contêm em si uma santidade oculta que possuí em latência um "segredo sagrado" que foi confiado a Igreja, como consta

\footnotetext{
12 Disponível em:

http://www.vatican.va/archive/cathechism_po/index_new/prima-pagina-cic_po.html

13 Disponível em: http://hjg.com.ar/sumat/index.html
} 
no próprio Catecismo da Igreja Católica, já referido aqui. Neste sentido, como quando no ocupamos do mistério como instituinte da fé, temos que os sacramentos ordenam e significam nossa santificação, a qual pode ser considerada sobre três aspectos, segundo Aquino (ST III, 60: 3), em especial, como

la causa de nuestra santificación, que es la pasión de Cristo; la forma de nuestra santificación, que consiste en la gracia y las virtudes; y el fin último de nuestra santificación, que es la vida eterna. Pues bien, todas estas cosas están significadas en los sacramentos. Por tanto, el sacramento es signo conmemorativo del pasado, o sea, de la pasión de Cristo; es signo manifestativo del efecto producido en nosotros por la pasión de Cristo, que es la gracia; y es signo profético, o sea, preanunciativo de la gloria futura.

Os sacramentos ${ }^{14}$ são, então, momentos de celebração da fé cristã 15 . E segundo o Catecismo da Igreja Católica são em número de sete $^{16}$, a saber: batismo, confirmação (ou crisma), eucaristia, reconciliação (ou penitência), unção dos enfermos, ordem e matrimônio. Neste sentido, como consta em São Tomás de Aquino (ST III, 73: 6; ST III, 65: 3; ST III, 63: 6) todos os sacramentos são ordenados para a eucaristia que é seu fim último. De modo que, nesta, renova-se o mistério e a celebração da fé e da comunhão com Jesus Cristo. E, neste sentido, como quer Bakthin (2012), tem-se que todas as categorias abstratas são, com isto, momentos constituintes de um certo todo, concreto, palpável e único que se manifesta no evento em processo, no momento de "agora' e, também, no "depois-de-agora".

Deste modo, tem-se que um ato ou ação executada por mim, enquanto ação responsável e da qual tenho consciência enquanto Ser no mundo da vida é, sob esta perspectiva, um ato que se assenta na obrigatoriedade assumida de minha realização na vida eterna que têm como base de seu reconhecimento o meu dever-ser. É aquilo que tenho como horizonte, como objetivo ainda por ser alcançado, ou seja, a comunhão com Deus e minha consagração através do corpo e sangue de Cristo. Assim, tem-se então que, na eucaristia, o corpo e sangue de Cristo em correlação comigo torna-se um objeto (ou símbolo) que só

\footnotetext{
14 Martinho Lutero define sacramento como um elemento, uma coisa material, que através da palavra de Deus, do verbo, da consubstanciação, vira uma coisa diferente. Mas não algo novo diferente daquilo que era, não no sentido material. $O$ vinho continua a ser vinho e pão continua a ser pão, mas pela promessa divina é atribuído um poder vinculado a essa matéria e aquilo que ela é e não é ao mesmo tempo, pão e corpo, vinho e sangue.

15 Muitos grupos protestantes veem os sacramentos apenas como sinais que estimulam a fé tais como os batistas e os pentecostais. Outros, como os Quakers, negam qualquer sacramento ou sua instituição. 16 Sobremaneira, tem-se que, na maioria das igrejas cristãs reformadas, principalmente as chamadas igrejas históricas, os sacramentos celebrados são apenas dois, quais sejam: o Batismo e a Eucaristia.
} 
têm sentido no evento em processo. $\mathrm{Na}$ unidade do evento real ${ }^{17}$ e no ato eucarístico $^{18}$ o objeto consagrado ${ }^{19}$ assume seu valor afirmado ${ }^{20}$. Isto posto, tem-se que, a eucaristia não pode realizar-se se não estabelecer uma relação entre aquilo que se realiza, o ato em si, e seu conteúdo em si, seu valor afirmado $^{21}$, através do caráter emocional-volitivo ${ }^{22}$ da experimentação ${ }^{23}$, da experiência e vivência da fé24.

\section{CONSIDERAÇÕES FINAIS}

No presente texto buscou-se pensar a eucaristia como ato e rito instituinte do sujeito, do Ser. São múltiplas vozes que sobre a égide da ciência moderna buscam pensar a relação do homem com o sagrado, seja no que se refere aos seus aspectos teológicos, litúrgicos, sociais, psico-sensoriais ou antropológicos. Em síntese defende-se aqui o argumento de que a eucaristia, seja enquanto ato, seja enquanto rito, nada mais é do que uma enunciação de si e sobre si.

\footnotetext{
17 A pravda.

18 A instina.

19 O pão e o vinho.

20 "De um objeto independentemente daquele contexto singular no qual ele me é dado naquele momento, mas expressa a verdade inteira da proposição na sua totalidade, como momento único e irrepetível que tem caráter de evento" (BAKTHIN, 2012, 1990).

$\mathbf{2 1}$ O qual têm seu substrato no reconhecimento da fé cujo referente está, segundo Bakthin (2012, p. 96), em "Neste preciso ponto no qual agora me encontro, nenhuma outra pessoa jamais esteve no tempo singular e no espaço singular que se dispõe todo o existir singular de modo singular e irrepetível. Tudo que é feito por mim não poderá nunca ser feito por ninguém mais, nunca. A singularidade do existir presente é irrevogavelmente obrigatória”. E, deste modo, a vivência ritual e a instituição do ser presente no ato eucarístico nos informa que aquilo que pode ser feito por mim não pode nunca ser feito por ninguém mais de modo que, a unicidade ou singularidade do ser presente no mundo é, forçosamente, obrigatória.
}

22 Que designa, segundo Bakthin (2012, p. 91) “o existir evento singular”, ou seja, o momento constituído pela experiência vivida do ser que a experimenta como uma experiência sua e que, a percebe como uma “orientação moralmente válida e responsavelmente ativa”.

23 De modo que, quando eu "penso num objeto estabeleço com ele uma relação que têm o caráter de um evento em processo" (BAKTHIN, 2012, p. 86). Pois, "a experiência real de um evento vivido possível é precisamente a sua inserção, a sua colocação em comunhão com o existir-evento singular” (BAKTHIN, 2012, p. 87). E, quando eu faço isso, eu reestabeleço "a unidade do motivo e da finalidade", da realização verdadeira e do sentido de seu conteúdo (BAKTHIN, 2012, p. 89). Este é modo pelo qual, segundo Bakthin (2012, p. 89) "uma consciência viva torna-se consciência cultural e, uma consciência cultural se encarna em uma consciência viva". Isso significa dizer que o experimentar da experiência e seu tom emotivovolitivo adquirem sua unidade no interior da cultura e que, fora dela, são casuais, e não, um evento em processo.

24 A fé compreende, dentro de uma perspectiva antropológica que reverbera na criação estética do enunciado e do ato executado, determinados valores culturais que são valores em si, os quais fundamentam-se em referenciais outros, nesse caso teológico-litúrgicos, que são em última análise a expressão do modo como compreendemos o mundo, de nossa cognição. 
É o modo como enunciamos para nós aquilo que queremos ser no devir. Contudo, tal enunciado discursivo só têm significado, manifesto em seu conteúdo-sentido, se enunciado por aquele que experimenta e executa o ato. Sua experimentação e vivência, por sua vez, só faz sentido no interior de certo campo de contingência, na integralidade do ato e na experimentação do mesmo por aquele que nele se reconhece.

Seu reconhecimento, enquanto sujeito que é instituído pelo rito eucarístico e que através dele entra em comunhão com Ele, com o sagrado, se dá através da fé. Fé que é verdade que se faz ser verdadeira (pravda) e instituinte (instina). Fé que se faz doxa e teoria explicativa do mundo. Fé que se faz mistério e faz da eucaristia o momento em que o homem se encontra com o sagrado, que com Ele comunga e que, a partir dele se faz Ser.

\section{REFERÊNCIAS}

BAKTHIN, M. Estética da criação verbal. São Paulo: Martins Fontes, 1992.

M. Para uma filosofia do ato responsável. São Carlos: João \& Pedro Editores, 2012.

BOURDIEU, P. Outline of a theory of practice. Cambridge: Cambridge University Press, 1977.

CARDITA, Â. Cristologia e Antropologia - Reconsideração teológica da mediação litúrgica. In: O Mistério, o Rito e a Fé: para uma 'recondução antropológica' da teologia litúrgico-sacramental. Lisboa: BonD, 2007. p. 183-262.

CASEL, O. A liturgia no âmbito do evento da revelação. In: O Mistério, o Rito e a Fé: para uma 'recondução antropológica' da teologia litúrgicosacramental. Lisboa: BonD, 2007. p. 333-372.

DURKHEIM, É. As formas elementares da vida religiosa: o sistema totêmico na Austrália. São Paulo: Martins Fontes, 1996.

GEERTZ, C. A interpretação das culturas. Rio de Janeiro: LTC, 1989.

LOWY, M. As aventuras de Karl Marx contra o Barão de Munchausen: marxismo e positivismo na sociologia do conhecimento. São Paulo: Cortez, 1996.

RAHNER, K. Os sacramentos no horizonte da antropologia transcendental”. In:

O Mistério, o Rito e a Fé: para uma 'recondução antropológica' da teologia litúrgico-sacramental. Lisboa: BonD, 2007. p. 271-332.

POPPER, K. Conjectures and Refutations. London: Routledge and Keagan Paul, 1963. 
SAUSSURE, F. Curso de Linguística Geral. São Paulo: Cultrix, 1996.

TURNER, V. W. O processo ritual. Petrópolis: Vozes, 1974.

WEBER, M. História geral da economia. São Paulo: Mestre Jou, 1968.

A ética protestante e o "espírito" do capitalismo. São Paulo: Companhia das Letras, 2004.

Recebido em 18/02/2015

Aprovado em 15/o4/ 2015 